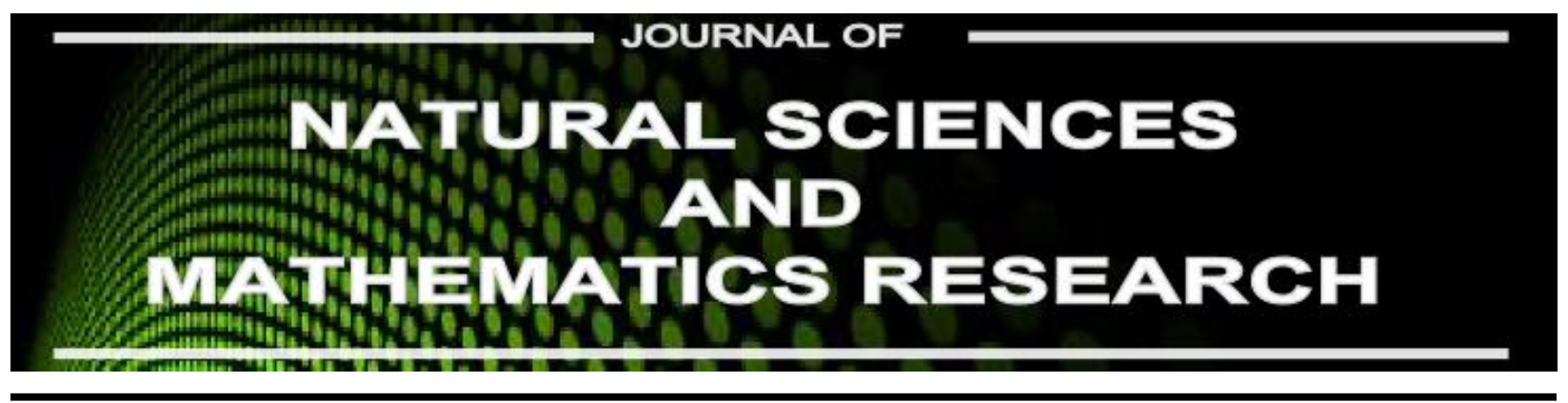

Available online at http://journal.walisongo.ac.id/index.php/jnsmr

\title{
The Application of Music Therapy For Children with Autism Based On Facial Recognition Using Eigenface Method
}

\author{
Hesti Khuzaimah Nurul Y.1, Ilona Usuman², Agfianto Eko Putra ${ }^{3}$, and Triyogatama Wahyu W. ${ }^{4}$ \\ ${ }^{1}$ Department of Physics, Faculty of Science and Technology, Universitas Islam Walisongo Semarang \\ 2,3,4 Dapartment of Computer Science and Electronics, Faculty of Mathematics and Natural Science, Universitas \\ Gadjah Mada
}

Corresponding author:
hestikhuzaimah@gmail.
com
Recived: 21 April 2017,
Revised : 27 May 2017
Accepted: 25 June 2017.

\section{Abstracts}

This research is motivated by the condition of children with autism who require continuous monitoring without a parent accompany, and certain therapies who is capable to reduce repetitive behaviors and increase the concentration. Music therapy is one of the treatment which able to perform it. The implementation of this research is located in a special schools with autism, the perform is proper at certain times and requires tools for music therapy. Therefore, the integrated device was made to monitor the activities of children with autism, as well as providing music therapy automatic face recognition based on Eigenface method.This device perform when the children with autism under certain conditions (e.g. crying, the teacher would not work orders, etc.), then by capturing the the facial image, the system will process to compare the similarity with the existing database. Then, the shortest distance of euclidean is chosen. If the captured of facial image is similar to the one existing database, then the music is performed as music therapy for children with autism. The results of this system, indicates that the child's responses become more calm, easy concentration, and the repetitive attitude is reduced. While the accuracy of the system achieves by $80 \%$ (compare with the old and new database) and $20 \%$. (without new database). (C2017 JNSMR UIN Walisongo. All rights reserved.

Key words: Autism; Music, Therapy; Face Recognition; Eigenface

\section{Introduction}

Nowadays, many therapies for autistic children, one of them is music therapy. This therapy is proven to assist the concentration of autistic children and reduce the repetitive behavior. In addition, music therapy is able to reduce the level of anxiety and emotional 
disturbance in a children with autism. Music therapy is also a funny game for them and helps the child become more relax.

The previous research on the music therapy for children with autism improve the concentration children. In addition, the children are more focused in learning [1]. Music therapy is also able to reduce repetitive behavior [2] [3]. The previous studies, the music therapy performed manually, because it still requires a musical instrument, and it takes a certain time for music therapy. There are several methods of music therapy as listening, mimicking, motion together, and others. All of these methods have their respective advantages [4]. However, the most effective and capable therapy at any time is the method of listening to music.

There are two methods of music therapy, first, the music therapy is directly performed by an autistic child. Second, the music therapy is played at certain moments. The second method of music therapy is the therapy that usual performs in special schools autism. This therapy also uses a musical instrument which directly shown by a music therapy teacher or with music that played in the same time, so this therapy is able to train the motoric ability and child concentration. If music therapy should be performed at any time, it will be less effective if the number of children with autism increases, while the teacher is limited. In addition, the emotional activity of children with autism is also unpredictable and monitoring to the children with autism still depend on the music teacher or parents. Therefore, the problem of this research is how the music therapy for children with autism performs automatically.

The implementation of this research, the music therapy is applied in a facial recognition system based on the Eigenface method. Previous research has used this method to recognize a person's face in realtime for home security [5]. Other researchers have also conducted research using eigenface method, and the results obtained is successfull [6]. From the results of their research, using Eigenface method in facial recognition capable obtained the percentage of success is high.
The purpose of this research is to develop the system of facial recognition Eigenface method that it is able to perform the chosen music therapy automatically according to the captured object. In addition, this music therapy is expected to increase the concentration and reduce repetitive behavior of children with autism.

\section{Experiments Procedure}

In this implementation, the system is built in order to capable to recognizes the facial image of the child with autism by searching the image of a very large image in a relatively short time. In addition, the system should be able to perform real-time image recognition as a reciprocal of a particular condition (e.g. crying, refusing teacher/parent commands, etc.) requiring music therapy to reduce repetitive behavior and to be concentrated.

Some autistic children have a strong pleasure in one color and find displeasure in other sound colors [7]. To support this research, the system to be built should be able to display the set of face image with a high similarity value to the face image of the input so that it can choose the suitable music for the child in accordance with the results. Music selection based on recommendations from music therapy teachers.

This system is designed to recognize a person's face to match the resemblance to the training image database, where the database contains the facial images of autistic children. If there is a resemblance to one of the image in the database, it will sound the music. In addition, the system is designed to be able to create a new database, so there is a database update.

This system begins with accessing the webcam. This stage is an early stage to know the quality of webcam is adequate. So get the frame to be processed in the next stage. The next process is to determine the image will be processed to create a new database or to perform face recognition process. If it will create a new database, then the next step to capture the image of the webcam. This image 
is ordered to be a new database. At this stage, image storage should be placed in the database folder. In addition, the image captured must be $200 \times 180$ pixels, so that it is similar to another database image. The naming of the new database image also uses a sequence numbering like any other database image.

The next stage is face recognition. At this stage, there are several major stages, namely the feature extraction of the facial image, which is to resize the image. The form of the image is changed from RGB to gray degree (grayscale). It is used to simplify the image model. Each color image consists of three layers of matrix, R-layer, G-layer and B-layer. When each calculation process is done using three layers, it means the same three calculations are performed. So the concept was changed by changing the 3 layers above into a gray-scale matrix layer and the result is a grayscale image. In this image there is no more color, there is a degree of gray. After that, the image is trained to reconstruct the image into a 2D matrix, so the eigenvalue and eigenvector are obtained. The result is used to calculate the eigenface value.

The next stage is to calculate the distance Euclidean to find the closest distance to the image of the input face. The closest distance is considered as the most similar face image. After getting the most similar image, live music automatically is appeared as music therapy for autistic children. Selection of this music based on the image of the most similar face on the database.

Music therapy applied for about 2 minutes. If in that time, there is no better response, then the operator will run the system again. This system is created using MATLAB software by utilizing Graphic User Interface (GUI).In this process, there is a function to get 2D matrix. At this stage, all images $(P)$ will be searched for the average image (m), after which searched the difference of each image to get the middle matrix of the vector image $(\mathrm{A})$. In the Eigenface method, it is necessary to find the Covarian matrix (L) to obtain the diagonal element of $\mathrm{D}$ which is the eigenvalue of $\mathrm{L}$ and $\mathrm{C}$. The coefficient matrix $\mathrm{C}$ or also called Eigenfaces is obtained from the eigenvector $L$, as can be seen in Figure 3.

To create a new database, incoming images are resized to $200 \times 180$ pixels. Then the image is named in the order of the last number in the training image. The flow chart of this system can be seen in Figure 5.

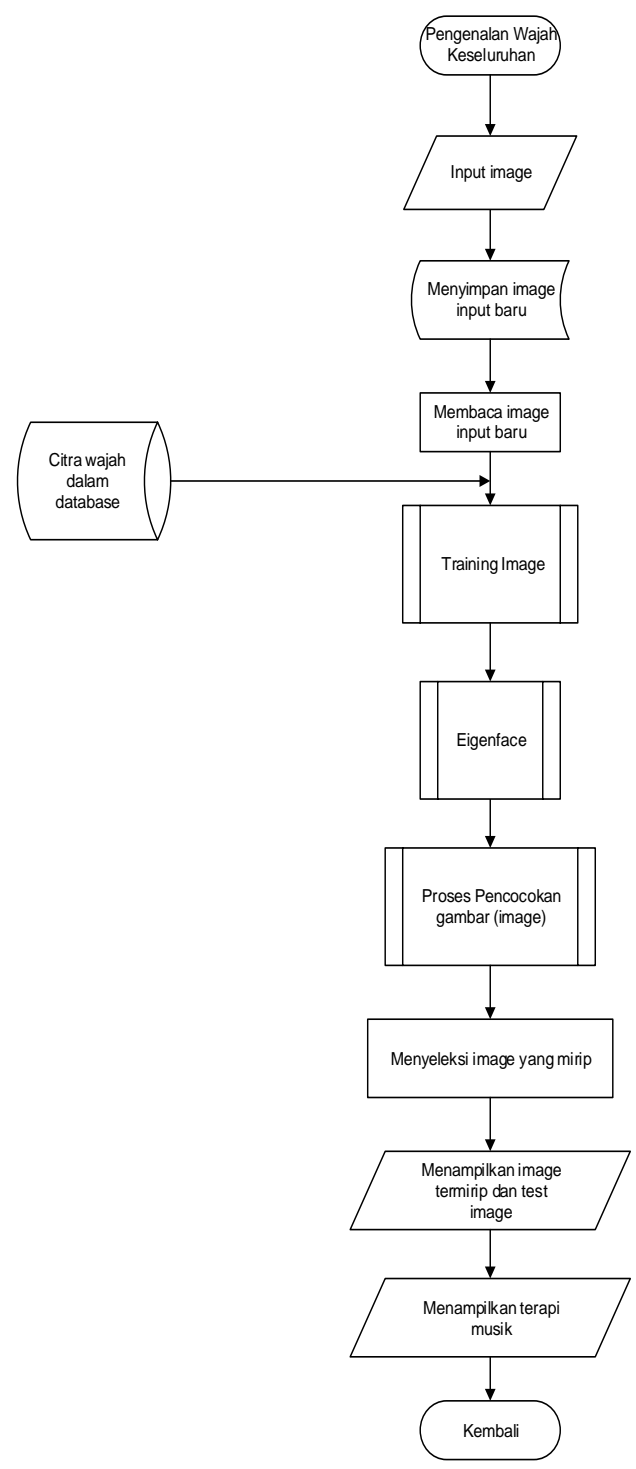

Figure 1. Flowchart Facial Recognition Process (overall)

For testing, the condition is designed, where the object (child with autism) is following the learning activities (KBM) which directly "face to face" with their teachers in a room. Then, the webcam as an object activity monitor, will be placed in a place that has been 
designed to be able to capture the object's face. Another solution if not possible to locates the webcam in a strategic place, then the webcam directed by researchers directly. Sound system in the form of portable speakers will be placed near the object, so the sound performed clearly by the object.

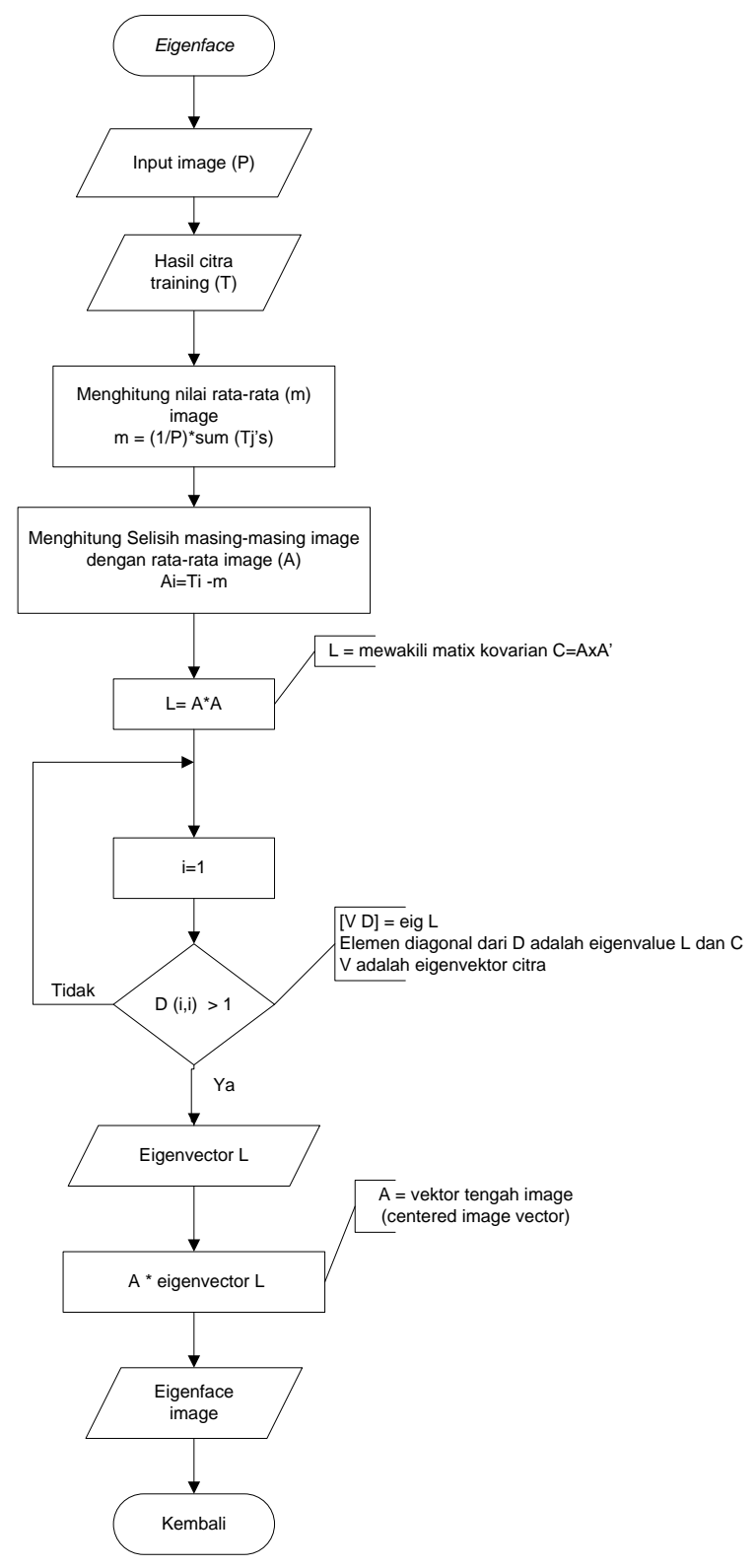

Figure 2. Flowchart Eigenface Process

The testing of system is also designed with two scenarios:

\section{The first scenario}

Directly test based on old database. That is, this test does not take a new sample of the child to be stored into a new database reference. So the database used is only the old database that must be the background conditions and lighting are different from the conditions during the test took place.

\section{Second Scenario}

Testing by adding new child photo samples to be used as a new database reference. In this test there will be old and new database face image as a comparative reference in the introduction of input facial image.

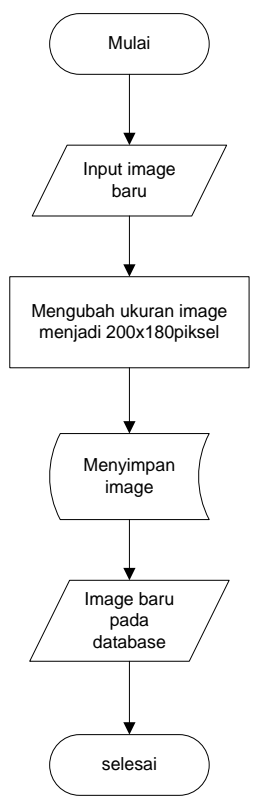

Figure 3. Flowchart for New Database

\section{Result and Discussion}

The implementation of Graphical User Interface (GUI) in MATLAB, as shown as in Figure 4, while to operate the system, there is a start menu that gives the option to perform the process of facial recognition or exit from the system. Implementation of the initial menu, as shown as in Figure 5. 


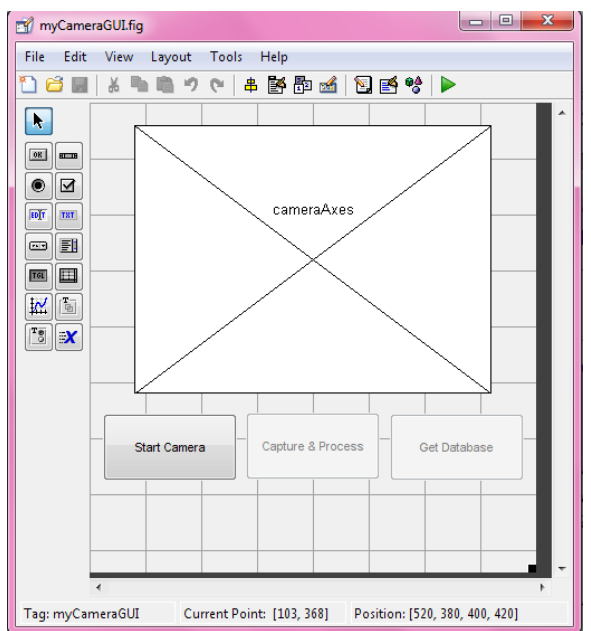

Figure 4. GUI Display

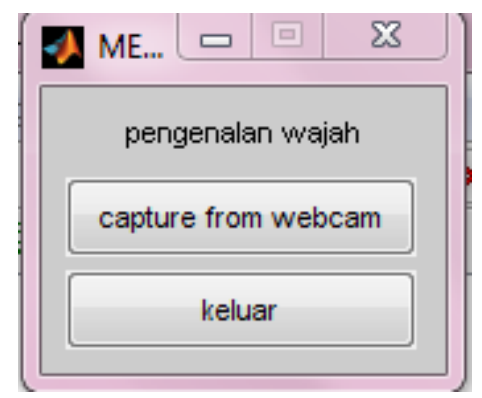

Figure 5. Display of Sytem Initial Menu
In this first scenario, it is performed fifteen times with five different objects, as shown as Table 1 . In this test, no new databases are taken. The existing database is the old database.Of the fifteen tests, twelve results were unsuitable, while three were appropriate. This can be seen in Table 2 . The percentage obtained from the success of the first scenario (without new database) is $20 \%$. This percentage is derived from the comparison of success with all experiments using the first scenario

Table 1. Testing Details with the First scenario

\begin{tabular}{ll}
\hline Testing1 & Object D (testing three times) \\
Testing 2 & Object I (testing three times) \\
Testing 3 & Object A (testing three times) \\
Testing 4 & Object F (testing three times) \\
Testing 5 & Object C (testing three times) \\
\hline
\end{tabular}

Tabel 2 The Testing Result of First Scenario

\begin{tabular}{|c|c|c|c|c|c|c|c|c|c|c|c|c|}
\hline \multirow[b]{2}{*}{ Subvak } & \multicolumn{4}{|c|}{ Pann--an ka-1 } & \multicolumn{4}{|c|}{ Panc-i, an kn-2 } & \multicolumn{4}{|c|}{ Pann-, n ka-3 } \\
\hline & $\begin{array}{c}\text { Jarke } \\
\text { Buclidan } \\
\text { tardaknt }\end{array}$ & $\begin{array}{l}\text { Tuming } \\
\text { dangu }\end{array}$ & $\begin{array}{l}\text { Roven } \\
\text { Sutan }\end{array}$ & Rasean Anak & $\begin{array}{c}\text { Jarke } \\
\text { Buclidan } \\
\text { tardaknt }\end{array}$ & $\begin{array}{l}\text { Tumith } \\
\text { danmen }\end{array}$ & $\begin{array}{l}\text { Musen } \\
\text { Siter }\end{array}$ & Raugen Anak & $\begin{array}{c}\text { Jnak } \\
\text { Buclidan } \\
\text { tardakn }\end{array}$ & $\begin{array}{l}\text { Tumitg } \\
\text { dangu }\end{array}$ & $\begin{array}{l}\text { Napen } \\
\text { Sitan }\end{array}$ & Masoen hak \\
\hline coseco 0 & $2.72208+28$ & 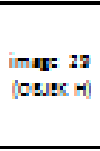 & $\begin{array}{l}\text { musik } \\
2 . w w v\end{array}$ & 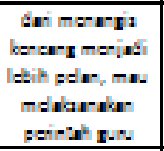 & 2.75018428 & $\begin{array}{l}\text { imas: } 22 \\
\text { (OEJEx n) }\end{array}$ & $\begin{array}{l}\text { musik } \\
\text { 2.ww }\end{array}$ & 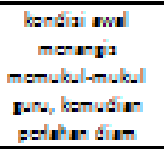 & 2..2725:-25 & $\begin{array}{l}\operatorname{imar}=20 \\
(0 s u s x)\end{array}$ & $\begin{array}{l}\text { muik } \\
\text { l.wwv }\end{array}$ & $\begin{array}{c}\text { fint, meren- } \\
\text { en umber } \\
\text { um }\end{array}$ \\
\hline Csus: I & 6.825:26 & imar: 18 & $\begin{array}{l}\text { murik } \\
2 . \mathrm{ww}\end{array}$ & 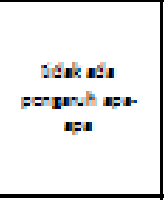 & 2.208427 & 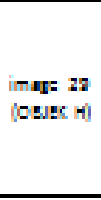 & $\begin{array}{l}\text { musik } \\
2 . w w\end{array}$ & letik senunt & 2.2013:-25 & $\begin{array}{l}\text { imar: } 54 \\
\text { (Osusx : }\end{array}$ & $\begin{array}{l}\text { muik } \\
\text { 1.wwv }\end{array}$ & 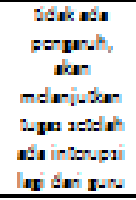 \\
\hline Coser $a$ & 6.708425 & $\begin{array}{l}\operatorname{imar:} 2 \\
\text { (Osusx s) }\end{array}$ & $\begin{array}{l}\text { muaik } \\
\text { a.wwv }\end{array}$ & $\begin{array}{c}\operatorname{mencan} 10 m b e \\
14 n\end{array}$ & $2.262+25$ & $\begin{array}{l}\text { imas: } 52 \\
\text { (Osusc n) }\end{array}$ & $\begin{array}{l}\text { musik } \\
\text { 3.ww }\end{array}$ & 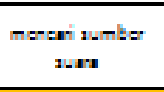 & 2.028028 & $\begin{array}{l}\text { imaress } \\
\text { (Osuex 1) }\end{array}$ & $\begin{array}{l}\text { murik } \\
\text { 3.wnv }\end{array}$ & $\begin{array}{c}\text { diam, menen- } \\
\text { en wumber } \\
\text { 1um }\end{array}$ \\
\hline coser. & 2.458428 & $\begin{array}{l}\operatorname{imar:2} \\
\text { (OEJEX A) }\end{array}$ & $\begin{array}{l}\text { musik } \\
2 . w w v\end{array}$ & 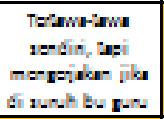 & 2.25828 & $\begin{array}{l}\text { i-n: } 28 \\
\text { (Osuse } n)\end{array}$ & $\begin{array}{l}m-1 k \\
3 . w w\end{array}$ & 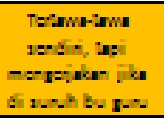 & 2.958428 & $\begin{array}{l}\text { imars } 50 \\
\text { (Osuex } 1)\end{array}$ & $\begin{array}{l}\text { muik } \\
\text { 3.wnv }\end{array}$ & 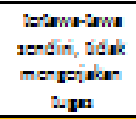 \\
\hline cosec 6 & 3.248428 & $\begin{array}{l}\text { i- or: } 10 \\
\text { (Ot;ike) }\end{array}$ & $\begin{array}{l}-u i k \\
2 . w n\end{array}$ & 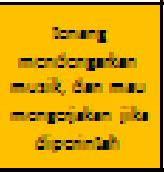 & 2.000426 & $\begin{array}{l}\text { imar: } 32 \\
\text { (cosex } 1)\end{array}$ & $\begin{array}{l}\text { musik } \\
\text { 3.ww }\end{array}$ & 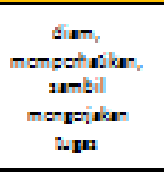 & 2.208428 & 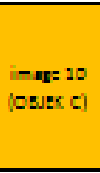 & $\begin{array}{l}-u k \\
2 . w n\end{array}$ & 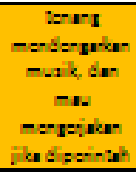 \\
\hline
\end{tabular}


In the second scenario, a new database is taken directly. The results obtained as shown as Table 4. In the fifteen times test, twelve times the corresponding match results, while three times unsuitable. Therefore, the accuration of this scenario is $80 \%$. This percentage is derived from the comparison of success with all experiments using the second scenario.

In response to the system, the same as the first scenario, because the system will respond by displaying classical music in accordance with the image obtained. As for the object response, various, as already mentioned in Table 4.

Table 3. Testing Details with the second scenario

\begin{tabular}{ll}
\hline Testing 1 & Object I (testing three times) \\
Testing 2 & Object A (testing three times) \\
Testing 3 & Object B (testing three times) \\
Testing 4 & Object H (testing three times) \\
Testing 5 & Object C (testing three times) \\
\hline
\end{tabular}

Tabel 4. The Testing Result of the second Scenario

\begin{tabular}{|c|c|c|c|c|c|c|c|c|c|c|c|c|}
\hline \multirow[b]{2}{*}{ Subyek } & \multicolumn{4}{|c|}{ Pengüian ke-1 } & \multicolumn{4}{|c|}{ Pengüian ke-2 } & \multicolumn{4}{|c|}{ Pengüian ke-3 } \\
\hline & $\begin{array}{c}\text { Jarak } \\
\text { Eudidean } \\
\text { terdekat }\end{array}$ & $\begin{array}{l}\text { Termirip } \\
\text { dengen }\end{array}$ & $\begin{array}{l}\text { Respon } \\
\text { Sistem }\end{array}$ & Respon Ansk & $\begin{array}{c}\text { Jarak } \\
\text { Eudidean } \\
\text { terdekat }\end{array}$ & $\begin{array}{l}\text { Termirip } \\
\text { dengen }\end{array}$ & $\begin{array}{l}\text { Respon } \\
\text { Sistem }\end{array}$ & Respon Ansk & $\begin{array}{c}\text { Jarak } \\
\text { Eudidean } \\
\text { terdekat }\end{array}$ & $\begin{array}{l}\text { Termirip } \\
\text { dengen }\end{array}$ & $\begin{array}{l}\text { Respon } \\
\text { Sistem }\end{array}$ & Respon Ansk \\
\hline OBIEKI & $7,40 E+15$ & $\begin{array}{c}\text { imsege } \\
29 \\
\text { (OBIEK I) }\end{array}$ & $\begin{array}{l}\text { musik } \\
2 . w a r\end{array}$ & $\begin{array}{l}\text { deri mensngis } \\
\text { kencang } \\
\text { menjodi lebih } \\
\text { peisn, meu } \\
\text { melskssnskan } \\
\text { perinteh guru }\end{array}$ & $5.08 E+15$ & $\begin{array}{l}\text { imege } 32 \\
\text { [OEIEK I] }\end{array}$ & $\begin{array}{l}\text { musik } \\
2 . w a r\end{array}$ & $\begin{array}{c}\text { dism, skan } \\
\text { meisnjutkan } \\
\text { tuges, jiks } \\
\text { diinstruksi oleh } \\
\text { guru }\end{array}$ & $2.67 \mathrm{E}+1 \mathrm{~s}$ & $\begin{array}{l}\text { imsge } 32 \\
\text { [OEIEK I] }\end{array}$ & $\begin{array}{l}\text { musik } \\
\text { 2.war }\end{array}$ & $\begin{array}{l}\text { dism, sksn } \\
\text { meisnjutkan } \\
\text { tuges, jiks } \\
\text { diinstruksi } \\
\text { oleh guru }\end{array}$ \\
\hline OBIEKA & $8.95 E+15$ & $\begin{array}{c}\text { image } 2 \\
\text { [OB]EK } \\
\text { A] }\end{array}$ & $\begin{array}{l}\text { musik } \\
2 . w 8 \%\end{array}$ & $\begin{array}{c}\text { mencari sumber } \\
\text { susrs }\end{array}$ & $783 E+15$ & $\begin{array}{l}\text { imege } 32 \\
\text { (OפEX D) }\end{array}$ & $\begin{array}{l}\text { musik } \\
2 \text { wav }\end{array}$ & $\begin{array}{c}\text { menceri sumber } \\
\text { suers }\end{array}$ & $1.55 E+16$ & $\begin{array}{l}\text { imege } 3 \\
\text { [OEEK A] }\end{array}$ & $\begin{array}{l}\text { musik } \\
2 \text { war }\end{array}$ & $\begin{array}{l}\text { mencari-gari } \\
\text { sumber susrs }\end{array}$ \\
\hline OBEK B & $5.78 E+15$ & $\begin{array}{c}\text { imsege } 8 \\
\text { |OBIEK. } \\
\text { B] }\end{array}$ & $\begin{array}{l}\text { musik } \\
1 \text { wer }\end{array}$ & $\begin{array}{l}\text { mesih tetep } \\
\text { menengis }\end{array}$ & $7.35 E+15$ & $\begin{array}{l}\text { imsge } 8 \\
\text { (Objek B] }\end{array}$ & $\begin{array}{l}\text { musik } \\
1 \text { wer }\end{array}$ & $\begin{array}{l}\text { mesih tetsp } \\
\text { menengis }\end{array}$ & $2.54 E+16$ & $\begin{array}{l}\text { imege } 28 \\
\text { (ODEK G] }\end{array}$ & $\begin{array}{l}\text { musik } \\
1 \text { wav }\end{array}$ & $\begin{array}{c}\text { tidak ads } \\
\text { pengaruh aps- } \\
\text { aps }\end{array}$ \\
\hline OEEK H & $5.78 E+15$ & $\begin{array}{c}\text { imsge } 16 \\
\text { [Objek } \\
\text { H] }\end{array}$ & $\begin{array}{l}\text { musik } \\
3 \text { war }\end{array}$ & $\begin{array}{c}\text { perilsku tetsp, } \\
\text { tepi lebih } \\
\text { mendengerken } \\
\text { guru }\end{array}$ & $3.02 E+15$ & $\begin{array}{l}\text { imege } 30 \\
\text { [OפEK H] }\end{array}$ & $\begin{array}{l}\text { musik } \\
3 . \text { war }\end{array}$ & $\begin{array}{c}\text { perilsku tetap, } \\
\text { tapi lebih } \\
\text { mendengarkan } \\
\text { guru }\end{array}$ & $5.73 E+15$ & $\begin{array}{c}\text { imsge } \\
\text { solobjek } \\
\text { H] }\end{array}$ & $\begin{array}{l}\text { musik } \\
1 \text { war }\end{array}$ & $\begin{array}{l}\text { perilsku mulsi } \\
\text { tidek teneng }\end{array}$ \\
\hline OBEXC & $4.22 E+15$ & imege 10 & $\begin{array}{l}\text { musik } \\
1 \text { war }\end{array}$ & $\begin{array}{c}\text { teneng } \\
\text { mendengarkan } \\
\text { musik, dan meu } \\
\text { mengerjakan } \\
\text { jika diperintah }\end{array}$ & $2.49 E+15$ & $\begin{array}{l}\text { imsege } 10 \\
\text { (OEIEK C) }\end{array}$ & $\begin{array}{l}\text { musik } \\
1 \text { war }\end{array}$ & $\begin{array}{l}\text { tensng } \\
\text { mendengerkan } \\
\text { musik, den meu } \\
\text { mengerjaken } \\
\text { jiks diperintsh }\end{array}$ & $1.93 E+15$ & $\begin{array}{l}\text { imege } 10 \\
\text { [OEIEKC) }\end{array}$ & $\begin{array}{l}\text { musik } \\
1 \text { war }\end{array}$ & $\begin{array}{c}\text { Tensng } \\
\text { menggerskkan } \\
\text { pensil, tapi } \\
\text { tidsk menulis } \\
\text { jiks tids ads } \\
\text { perinteh }\end{array}$ \\
\hline
\end{tabular}

From Table 2 and Table 4, it is seen that in the first scenario of 3 times test with 5 objects, 3 successes were obtained. In the second scenario, with an object of five, and testing for three times, success is twelve times. Therefore, it can be concluded, with the overall test that is 30 times, the success of the system in the face recognition as much as fifteen (15) times, so that the percentage of successful face recognition as a whole either by using a new database or not, by $50 \%$.

From the tests conducted on 6 objects it can be seen that the direct response of objects after classical music appears in accordance with the results of each similarity, whether appropriate or not appropriate, the results obtained that the response of most objects become more calm, such as Object D and Object B Who cried more slowly and began to listen to what the teacher said. Then Object $\mathrm{H}$ becomes more calm and cares for the teacher. Then Object $\mathrm{C}$ no longer moves its pencil when bored on the task of the teacher, although Object $\mathrm{C}$ still does not do the job given by the teacher, but repetitive behavior is more decreased.

The music recommendations for each student are different. However, the third recommended music is the same kind of classical music, so most of the visible responses are the same even though the music 
that appears different from the recommendations contained in the program.

\section{Conclusion}

Based on the results of the research up to the test, it can be concluded as follows, The immediate response of some objects after getting this music therapy is the object becomes more calm and listen to the teacher's command, focus on the task, and repetitive behavior is no longer beat the pencil. An integrated device monitoring system of activity and music therapy using webcam and face-based recognition with Eigenface method when used for indoors has a 50\% accuracy of the tested sample. Taking a new database when going to use this system is very good, because it will increase the similarity. This is seen from the results of similarities with the old database (first scenario) has a low similarity of $20 \%$, while using a new database that is always updated its accuracy, the results obtained much better is $80 \%$.

\section{Acknowledgement}

Thanks to Sekolah Khusus Autis Fajar Nugraha Yogyakarta for providing fruitful discussion and data.

\section{References}

[1] P. Kern, Making Friend In Music; Including with Autism in an Interactive Play SettingMusic Teraphy Today, http://musictheraphytoday.net, accesed 1 January 2013.

[2] STEER, Music Theraphy For Children With Autistic Specrum Disorder, http://www.wihrd.soton.ac.uk/proix/sign _post/steers/steer-2004 (1).pdf. , accesed 1 January 2013.

[3] A. Chandra, Terapi musik untuk mengurangi perilaku repetitif pada anak autis, Thesis, Jurusan Psikologi UGM, 2007.
[4] M. Anugroho, Terapi Musik Pada Autis, Modul Pada Autism Short course, Yogyakarta, 2006.

[5] S. Bayu, A. Hendriawan, dan R. Susetyoko, Penerapan Face Recognition Dengan Metode Eigenface Dalam Intelegent Home Security. ITS, Surabaya, 2011.

[6] N.E. Diana, Sistem Temu Kembali Citra Wajah Berbasis Eigenface, Skripsi, Fakultas Ilmu Komputer , Universitas Indonesia, 2007.

[7] The National Autistic Society, Music Theraphy, http://www.nas.org.uk/nas/jsp/polopoly. jsp , accessed 24 Desember 2012. 